\title{
ECO-PEDAGOGI BERBASIS RELIGI BAGI MASYARAKAT PESISIR TUBAN
}

\author{
M. Thoyyib, Mujib Ridlwan, Zakiyah Kholidah
}

Institut Agama Islam Al Hikmah Tuban

Jl. PP. Al Hikmah, Tuban, Jawa Timur

e-mail: jatisari@gmail.com,cak_mujib_ridlwan@yahoo.com, zakiyahkholidah@gmail.com

\begin{abstract}
Abstrak: Penelitian ini bertujuan untuk menganalisis kegiatan Eco-Pedagogi berbasis religi bagi masyarakat Pesisir Tuban. Penelitian ini didasari atas stigma masyarakat nelayan yang dikenal kumuh dan jauh dari kepedulian lingkungan. Oleh karenanya diperlukan satu kegiatan berbasis pendidikaan yang dapat merubah karakter masyarakat pesisir tersebut. Penelitian dilaksanakan pesisir Jenu, Tuban, Jawa Timur dalam kurun waktu selama enam bulan sejak pertengahan sampai akhir 2016. Penelitian ini menggunakan penelitian kualitatif. Dua tahapan dilakukan selama penelitian, yaitu mengetahui tingkat pemahaman agama masyarakat pesisir terutama terkait dengan teks pelestarian lingkungan dan menginternalisasi nilai-nilai teks wahyu melalui pendekatan agama. Hasil penelitian menunjukkan bahwa masyarakat pesisir Tuban dikenal sebagai masyarakat yang religius, namun di satu sisi juga dikenal kumuh. Agama menjadi dasar untuk mereka dalam mendidik perilaku peduli pada lingkungan. Beberapa hal telah dilakukan dalam eco-pedagogi berbasis religi bagi masyarakat pesisir Tuban, diantaranya: pemahaman masyarakat terhadap ayat-ayat Al-Qur'an yang berisi tentang kepedulian terhadap lingkungan, membangkitkan kesadaran masyarakat mencintai lingkungannya, Membangun keterlibatan stakeholders sehingga saling bersama untuk peduli terhadap lingkungan.
\end{abstract}

Kata Kunci: Eco-Pedagogi, Lingkungan, Religiousitas

Abstract: This study aims to analyze the activities of religious-based EcoPedagogy for the Tuban Coastal community. This research is based on the stigma of the fishing community which is known to be slum and far from caring for the environment. Therefore, an education-based activity is needed that can change the character of the coastal community. The research was conducted on the coast of Jenu, Tuban, East Java for a period of six months from mid to late 2016. This study used qualitative research. Two stages were carried out during the research, namely knowing the level of religious understanding of coastal communities, especially related to environmental preservation texts and internalizing the values of revelation texts through a religious approach. The results show that the coastal community of Tuban is known as a religious community, but on the one hand it is also known as slums. Religion is the basis for them in educating the behavior of caring for the environment. Several things have been done in religious-based ecopedagogy for the coastal community of Tuban, including: understanding the community towards the verses of the Qur'an which contain concern for the environment, raising public awareness of loving the environment, building stakeholder involvement so that they are together to care for the environment.

Keywords: Eco-Pedagogy, Enviroment, Religious 
Hikmah, Vol. 18, No. 2, Juli-Desember 2021， p-ISSN: 1829-8419 e-ISSN: 2720-9040

\section{PENDAHULUAN}

Persoalan lingkungan menjadi isu global yang sampai sekarang masih sangat aktual dibicarakan. Tidak heran, di beberapa belahan dunia muncul organisasi-organisasi internasional yang konsentrasi pada persoalan lingkungan, termasuk memunculkan-kelompok-kelompok kajian yang bergerak untuk mensosialisaikan persoalan lingkungan, dengan tujuan utamanya melindungi lingkungan dari kerusakan dan menjaga ekosistem. Penipisan ozon, menipisnya udara sehat, dan pentingnya lingkungkan sehat bagi manusia menjadi alasan pentingnya pelestarian lingkungan. (Keraf, 2010).

Bagian dari pusat perhatian para aktifis lingkungan adalah tentang kebersihan air yang bermuara salah satunya pada pantai bahkan menjadi perhatian serius, karena bibir pantai menjadi salah satu pintu gerbang masuknya penyebab tercemarnya air laut. (Yasril \& Nur, 2018). Dalam penelitian ini, penulis mengambil obyek penelitian dari bagian yang sangat kecil di dunia, masyarakat yang berpenghuni di pinggir pantai, yaitu masyarakat Kecamatan Jenu, Kabupaten Tuban.

Sebagaimana umumnya masyarakat pesisir, masyarakat Jenu juga masih mengalami kemandegan kesadaran dalam membangun lingkungannya yang bersih dan sehat. Sebut salah satunya, desa Kaliuntu, yang merupakan desa yang bertempat tinggal bersebalahan persis dengan pantai utara yang mempertemukan desa Kalintu dengan Laut Jawa di Tuban, Jawa Timur. Beberapa desa di pesisir Kecamatan Jenu, Kabupaten Tuban, Jawa Timur kondisi lingkungannya masih tergolong tidak sehat, karena banyak hewan ternak yang ditempatkan di pelataran depan rumah dan sekeliling rumah warga, salah satunya adalah di desa Kaliuntuk, terutama di dusun Tajung. Dusun yang berpenghuni sejumlah 55 Kepala Keluarga (KK) dengan jumlah 320 warga itu, jauh dari kategori lingkungan sehat. Bahkan menurut penjelasan Camat Jenu, Drs, H. Kasmuri, Dusun Tajung, Desa Kalintu, Kecamatan Jenu merupakan lokasi tergolong paling kumuh di seluruh wilayah Tuban. Inilah yang memantik reseacher melakukan penelitian di lokasi ini dengan mengambil tema, "Eco-Pedagogik Berbasis Religi: Upaya Internalisasi Nilai-nilai Ramah Lingkungan Berbasis Agama bagi Masyarakat Pesisir Tuban.”

Kondisi masyarakat pesisir Tuban merupakan kaum agamis, tetapi belum memiliki kesadaran membangun lingkungan bersih, menjadi sebuah pertanyaan, seberapa kuat nilai-nilai ajaran agama mereka marasuk menjadi sebuah tindakan. Inilah pentingnya penelitian ini dengan mengunggah masalah, bagaimana upaya internalisasi nilai-nilai ramah lingkungan berbasis religi. Tujuannya, masyarakat mengalami kesadaran dalam menjalan nilainilai agama, terutama dalam menjalankan perintah menciptakan dan menjaga lingkungan yang bersih dan sehat.

Terdapat beberapa penelitian yang relevan dengan penelitian ini, seperti ekopedagogik di sekolah alam (Yunansah et al., 2020), ecopedagogi untuk kelangsungan lingkungan yang bebas dari praktik kapitalisme (Kahn, 2008), ecopedagogi dan kesehatan siswa (Smith, 2021), ecopedagogi 
dan eksploitasi lingkungan (Ilyasa et al., 2020), pendidikan Islam dan kesadaran terhadap kepedulian lingkungan (Nurulloh, 2019), menjaga lingkungan perpspektif Islam (Afrina, 2020), konstuksi pendidikan kesehatan lingkungan dalam perpektif Islam (Efendy, 2016), dari beberapa penelitian tersebut terdapat gap dengan penelitian yang dilakukan ini, yakni fokus penelitian ini basis keislaman, dan khususnya lagi tidak pada siswa melainkan pada masyarakat Pesisir Tuban. Yang mana masyarakat pesisir dikenal akrab dengan religiusitas, namun juga dikenal tidak akrab merawat lingkungan, tentu lah kiranya diperlukan pemberian kesadaran tentang eopedagogi dengan memanfaatkan asset mereka berupa kearaban mereka terhadap nilai-nilai agama yang selama ini mereka yakini.

Penelitian ini bertujuan untuk menganalisis kegiatan Eco-Pedagogi berbasis religi bagi masyarakat Pesisir Tuban. Penelitian ini didasari atas stigma masyarakat nelayan yang dikenal kumuh dan jauh dari kepedulian lingkungan. Oleh karenanya diperlukan satu kegiatan berbasis pendidikaan yang dapat merubah karakter masyarakat pesisir tersebut. Fokus kajian pada dua hal yakni kajian tentang ayat-ayat yang dipergunakan untuk membagun kesadaran masyarakat pesisir terhadap kepedulian lingkungan, dan hal yang dilakukan terhadap masyrakat dalam hal membangun kesadaran kepedulian lingkungan.

\section{METODE PENELITIAN}

Penelitian ini menggunakan pendekatan penelitian kualitatif, berbasis studi kasus. Kasus pencemaran lingkungan yang terjadi di pesisir tuban menjadi dasar permasalahan penelitian. Pola pemberian kesadasaran dan pembinaan masyarakat berbasis Asset Based Community Deelopment (ABCD), Masyarakat pesisir Tuban memiliki asset berupa masyarakat yang meyakini nilai-ilai atau tradisi keagamaan, hal ini tampak pada adanya ritual-ritual keagamaan yang menyelingi kegiatan para nelayan.ritualitas bukan hanya terjadi pada daerah nelayan saja akan tetapi beberapa tempat di Indonesia juga melakukan yang sama, bahkan diidentikkan dengan ritualitas keagamaan. (Imanda et al., 2021).

Pengumpulan data menggunakan teknik observasi, wawancara, dan dokumentasi. Observasi untuk mengamati secara langsung kegiatan ecopedagogi yang berlangsung di daeran pesisir tuban, dan kontak lansung masyarakat melestarikan lingkungan berbasis keagamaan. Wawancara untuk mendapatkan informasssi seputar kegiatan ecopedagogi, ragam kegiatan dalam hal keasadaran lingkungan. Dokumentasi untuk melihat potret dokumen yang berkaitan dengan pelestarian lingkungan seperti aturan, kebijakan, atau materi pendidikan ecopedagogi.

Analisis data menggunakan tahapan Miles dan Huberman, yang terdiri dari beberapa tahapan yakni reduksi data, organisasi data, dan penarikan simpulan. Teknik penjamin keabahan data dilakukan menggunakan member crosscheck dan trianggulasi data. Deskripi data dilakukan dengan terlebih dahulu menganalisis dengan didasarkan pada interpretasi peneliti. 
Hikmah, Vol. 18, No. 2, Juli-Desember 2021， p-ISSN: 1829-8419 e-ISSN: 2720-9040

\section{HASIL DAN PEMBAHASAN}

Sebelum menjelaskan lebih lanjut tentang temuan penelitian, maka akan didesripsikan terlebih dahulu tentang profil dan demografi lokasi penelitian, hal ini bertujuan untuk memberikan pemahaman utuh terhadap temuan penelitian nantinya:

\section{Profil dan Demografi Singkat Kaliuntu}

Kecamatan Jenu, merupakan

Kecamatan yang berada dalam naungan administrasi Kabupaten Tuban, Jawa Timur dengan posisi bagian utara bersebalahan dengan Laut Jawa, Bagian Barat bersebelahan dengan Kecamatan Tambakboyo, Bagian Timur bersebelahan dengan Kecamatan Kota Tuban, Bagian Selatan bersebelahan dengan Kacamatan Merakurak. Terdapat 17 desa yang tersebar di wilayah Jenu, dengan mayoritas pekerjaan warganya selain sebagai nelayan, petani, juga sebagai peternak hewan paling banyak peternak hewan sapi. (Sukma, 2017).

Desa Kalintu merupakan satu dari 17 desa yang tersebar di wilayah Tuban. Desa Kaliuntu memiliki beberapa dusun, salah satunya dusun Tajung yang tergolong lingkungannya masih kotor, karena oleh beberapa sebab, diantaranya, irigasinya tidak tersedia dengan baik, ternak sapi dan tempat pembuangan kotoran sapi ditempatkan di sembarang tempat. Hampir semua yang memiliki ternak sapi--bukan hanya di dusun Tajung-- di pusat administrasi Desa Kaliuntu juga masih menempatkan sapid an kotorannya di sembarang tempat. Akibatnya, bau tidak sedap selalu terasa di waktu kapanpun. Belum lagi ditambah dengan bau tidak sedap dari jemuran ikan yang dilakukan oleh sebagian masyarakat nelayan di Desa Kaliuntu. Inilah yang menjadi problem masyarakat Desa Kalintu, terkait lingkungan. (Suwarsih, 2018).

Terkait kebersihan, dari wilayah Kaliuntu yang terparah adalah dusun Tajung, Dusun Tajung merupakan dusun yang baru terbentuk pada tahun 1980, yang penduduknya berasal dari Desa Blarak, Kecamatan, Jenu, Kabupaten Tuban, Jawa Timur. Dusun Tajung secara adminitrasi masuk desa Keliuntu, Kecamatan Jenu, Kabupaten Tuban, Jawa Timur terletak persis di bibir pantai Laut Jawa, berjarak dari pusat kota Tuban sekira pukul $10 \mathrm{~km}$. Penduduknya hanya berjumlah 44 Kepala Keluarga (KK) dengan jumlah penduduk 145 orang dengan mata pencaharian nelayan, petani, dan beternak (terutama ternak sapi).

Sebelum tahun 1980, luas dusun Tajung yang tidak lebih 3 hektar itu hanya berbentuk persawahan. Lahan ini mulai ditempati setelah terjadi pemindahan warga yang sebelumnya tinggal di desa Blarak (berjarak sekitar $3 \mathrm{~km}$ dari dusun Tajung) menyusul pembangunan Pembangkit Listrik Tenaga Uap (PLTU), yang memindahkan semua warga Blarak. Warga Blarak sebelum tahun 1980, hidup dalam satu perkampungan, kemudian tiba-tiba mereka 'dipaksa' pindah karena di desanya tinggal dibangun PLTU. Warga Blarak kemudian pindah ke tempat berbeda dengan cara berpencar, sebagian tinggal di Desa Kaliuntu, sebagian lain memilih tinggal di desa Wadung, Kalirejo (semuanya masuk Kecamatan Jenu). Tetapi sebagian besar dari mereka memilih tempat baru yang belum dihuni orang, yaitu di sebuah lahan di pinggir pantai, yang kemudian belakangan 
dikenal dengan sebutan dusun Tajung. Mereka membeli tanah milik salah satu warga Kaliuntu, harganya Rp 5.000 permeter.

Mereka memulai hidup baru di tempat yang sama sekali belum pernah dibayangkan sebelumnya. Warga Blarak yang pindah ke Tajung, waktu itu hanya sekitar $20 \mathrm{KK}$, tetapi seiring perkembangan waktu jumlah itu mengalami perkembangan menjadi 44 KK. Kepindahan ini memporak-porandakan tatanan sosial yang sebelumnya sudah mapan, termasuk pendidikan putra-putri mereka. Pengakuan pemuda Tajung dan Kades Kaliuntu menjadi penguat bahwa pendidikan putra-putri mereka terabaikan. Meski di desa Kaliuntu yang berjarak hanya sekitar $1 \mathrm{~km}$ terdapat sekolah mulai jenjang TK s/d Madrasah Aliyah (setingkat SMA), tetapi pendikan anak-anak warga dusun Tajung masih belum beranjak tersadarkan pentingnya pendidikan untuk masa depan anak-anak mereka. Hasil wawacara dengan Kepala Desa Kaliuntu, sebagai berikut:

"Pendidikan anak-anak dusun Tajung memang masih memprihatinkan. Sebagian besar belum merasakan bangku sekolah setingkat SMA. Mereka yang duduk di SMP-pun sangat sedikit, apalagi kuliah. Sebagian besar hanya lulus SD. Inilah bagian dari kendala untuk hidup lebih sehat dan bersih. Mereka belum sadar pendidikan itu penting untuk meningkatkan kehidupan mereka."

Dari sisi kebersihan, masyarakat Tajung yang menjadi fokus obyek penelitian di Kecamatan Jenu, bisa dikatakan sebagai masyarakat yang belum peduli terhadap kebersihan lingkungan. Pemandangan tidak sedap dari kotoran ternak sapi terlihat di mana-mana, menyusul penempatkan kotoran dan penempatan ternak sapi yang tidak pada tempatnya. Hasil pengamatan reseacher, ternak sapi ditempatkan di depan rumah atau sebagian lain di sampaing rumah. Bukan hanya itu, kotoran sapi juga berserakan ke jalan yang ada di tengah kampung. Saat resecher memasuki dusun Tajung, kesan pertama kali yang dirasakan adalah bau tidak sedap yang berasal dari kotoran sapi, apalagi saat musim hujan, bukan hanya bau tidak sedap yang dirasakan, tapi juga luberan kotoran sapi ke tengah ruas jalan yang membentang sepanjang jalan di dalam kampung (jalan paving yang berada di dalam dusun Tajung).

Tentu berdasarkan logika umum manusia, kondisi ini merupakan situasi yang dapat mengganggu masyarakat setempat dan setiap tamu yang datang ke dusun Tajung. Meski logika umumnya demikian, tetapi masyarakat Tajung merasa tidak terganggu dengan bau tidak sedap dari kotoran sapi yang berserakan di sekitar rumahnya bahkan tidak jarang terlihat mereka makan di dekat sapi maupun kotoran sapi yang sengaja di tempatkan di samping kanan-kiri rumah maupun depan rumah masyarakat. Bagi masyarakat kondisi seperti itu tidak masalah dan tidak dirisaukan, karena masyarakat telah mampu beradaptasi dengan lingkungannya yang kotor. Tetapi logika masyarakat umum, tidak sama dengan logika yang dibangun masyarakat setempat yang berbasis adaptif terhadap kondisi lingkungan abnormal (lingkungan di mana masyarakat pada umumnya tidak bisa menerima lingkungan dengan tingkat kekotorannya tinggi).

Tetapi bagi negara, berkewajiban untuk 
Hikmah, Vol. 18, No. 2, Juli-Desember 2021， p-ISSN: 1829-8419 e-ISSN: 2720-9040

memberikan perlindungan kepada warganya dari lingkungan tidak sehat. Lingkungan hidup yang baik dan sehat merupakan hak asasi setiap warga negara Indonesia sebagaimana diamanatkan dalam Undangundang Negera Republik Indonesia. Bau tidak sedap tidak menjadi masalah bagi masyarakat, bisa disebabkan oleh beberapa kemungkinan, di antaranya; Pertama, bisa disebabkan masyarakat sudah tidak peka lagi terhadap bau tidak sedap, karena setiap hari dan berlangsung dalam waktu lama sudah menghirup bau tidak sedap dari kotoran sapi; Kedua, disebabkan masyarakat dengan bahasa 'terpaksa' mau hidup dengan lingkungan tidak sehat, karena keterpaksaan ekonomi (kebutuhan ekonomi yang mendorong dan memotivasi untuk hidup dalam lingkungan tidak sehat).

\section{Kondisi Masyarakat Desa Kaliuntu: Pendidikan Rendah-Ekonomi Lemah}

Kondisi ekonomi dan pendidikan masyarakat Desa Kaliuntu berada di bawah rata-rata. Lebih detil tentang kondisi masyarakat, bisa dilihat pada penjelasan di bawa ini:

\section{a. Kondisi kesehatan}

Kondisi kesehatan lingkungan masyarakat Dukuhan Tajung jauh dari ukuran sehat menurut ukuran masyarakat umum. Hasil riset, ditemukan banyak sapi yang kandangnya berada persis di depan rumah dan di samping rumah tempat tinggal mereka. Kotoran-kotoran sapi banyak berserakan ke jalan-jalan raya karena jarak antara rumah dengan tempat sapi sangat dekat. Hampir sebagian besar sapi ditempatkan di depan maupun samping rumah. Saat survey kedua berlangsung, hujan sedang berlangsung dan kotoran sapi mengeluarkan bau tak sedap. Meski demikian, warga Kaliuntu mengaku sudah biasa dengan bau kotoran sapi. Tapi bagi reseacher, bau itu membuat mual-mual perut, meski harus menahan diri agar warga tidak tersinggung.

Kondisi seperti ini belum disadari masyarakat, bahwa kotoran itu bisa mengganggu kesehatan mereka. Sampai sejauh ini, karena warga Dukuhan Tajung tidak banyak memiliki lahan pertanian, kotoran sapi dijual atau ditukar makanan sapi kepada petani asal Kecamatan Merakurak, yang berjarak sekitar $10 \mathrm{~km}$ dari Dukuhan Tajung. Namun sebagian lain ditukar dengan bahan makanan, seperti singkong yang sudah dikeringkan. Tetapi, kotoran sapi itu tidak setiap minggu bisa diambil, namun nunggu sampai beberapa bulan baru ditukarkan. Karenanya, kotoran sapi menumpuk dan meluber ke tengah jalan perkampungan Desa Kaliuntu.

Sapi-sapi itu tidak ditempatkan di lokasi jauh dari perkampungan warga desa Kaliuntu, karena mereka tidak memiliki lahan untuk menempatkan sapi jauh dari perumahan. Pertimbangan lain juga soal keamanan sapi, meski punya lahan sapi-sapi itu tidak bisa ditempatkan di lokasi yang jauh dari pemiliknya, alasannya, khawatir sapisapi itu dicuri oleh orang-orang jahat. Kondisi ini tentu membutuhkan solusi cerdas untuk mengubah lingkungan tidak sehat menjadi sebuah lingkunga asri dan ramah lingkungan.

b. Kondisi ekonomi

Rata-rata kehidupan masyarakat desa Kaliuntu masih di bawah garis kemiskinan. 
Tumpuan perekonomian mereka menggantungkan pada pantai, buruh tani, serta pejualan terasi. Masyarakat nelayan Dukuhan Tajung hanya mengandalkan kekuatan kakinya untuk menyisir pantai guna memperoleh ikan-ikan ukuran kecil, seperti ikan rebon. Sepulang dari menyisiri pantai, ikan yang didapat diserahkan kepada istriistri mereka untuk dikelola. Ikan lainnya dijual mentah, sedangkan ikan rebon dilembutkan untuk digunakan bahan terasi. Jika musim panen rebon, setiap nelayan bisa memperoleh ikan rebon dalam kondisi basah antara 30-40 kg perhari. Harga rebon basah antara bisa dijual Rp 5.000/kg. Artinya jika musim panen rebon, perharinya setiap nelayan bisa memperoleh penghasilan $\mathrm{Rp}$ 150.000 - 200.000. Dalam setahun perolehan seperti yang digambarkan di atas hanya berlangsung kira-kira 2 bulan, selebihnya penghasilan mereka rata-rata Rp 30.000 40.000/hari.

Dari rebon itu, sebagian besar digunakan terasi, sebagian lain dijual mentah. Meski dijual sudah dalam bentuk terasi, tetapi terasi itu tidak dikemas atau diolah sebagaimana industri terasi sehingga mempengaruhi harga jual. Yang mestinya terasi yang sudah dikemas bisa laku Rp 40.000-50.000/kg, tapi karena terasi hasil produksi warga Dukuhan Tajung ini tanpa dikemas hanya laku Rp 25.000/kg.

Warga Dusun Tajung, selain pekerjaan sehari-harinya sebagai nelayan, juga berternak sapi. Catatan reseacher yang dikumpulkan dari keterangan warga, mayoritas warga Dusun Tajung berternak sapi. Dari 44 Kepala Keluarga (KK), hanya tersisa $10 \mathrm{KK}$ yang tidak merawat sapi, selebihnya 34 KK merawat sapi. Jumlah sapi yang dimiliki masing-masing KK bervariatif, ada satu KK yang merawat dua ekor sapi, dan banyak KK yang merawat lebih.

Bagi masyarakat Tajung, ternak sapi merupakan bagian dari tumpuan hidup, selain sebagai nelayan. Tetapi sayangnya, ternak sapi yang dinilai sangat baik untuk mensuport ekonomi mereka, justru menjadikan kampung hunian masyarakat desa Kaliuntu menjadi tempat yang kumuh tidak sehat. Masyarakat Kaliuntu tidak mampu mengelola kotoran sapi menjadi bernilai ekonomi, sementara di lain hal mereka tidak mampu menjauhkan kotoran sapi itu dari rumah-rumah hunian masyarakat Kaliuntu disebabkan tidak memiliki lahan lain.

"Saya sebenarnya sangat senang hidup bersih, tetapi sayangnya kami tidak memilihi lahan lain untuk menempatkan sapi agar jauh dari hunian. Masyarakat sudah terbiasa dengan kondisi lingkungan seperti ini. Meskipun bau tidak sedap setiap hari dirasakan, tetapi warga menganggap sesuatu yang biasa, karena sudah terbiasa,

Inilah yang menyebabkan, masyarakat Kaliuntu tidak segera beranjak untuk menata lingkungannya dari lingkungan kumuh menjadi lingkungan bersih. Masyarakat Kaliuntu masih tetap bertahan dengan kondisi lingkungan kumuh, untuk mempertahankan hidupnya---dengan bertumpu pada hasil ternak sapi. Tumpukan kotoran sapi berserakan di mana-mana, samping, depan, dan belakang rumah mereka. Tentu kondisi ini sangat tidak sehat menurut ukuran manusia pada umumnya 
Hikmah, Vol. 18, No. 2, Juli-Desember 2021， p-ISSN: 1829-8419 e-ISSN: 2720-9040

c. Kondisi Pendidikan

Kondisi pendidikan Dukuhan Tajung sampai sekarang bisa dikatakan masih memprihatinkan. Barometernya, sampai sejauh ini belum ada satupun pemuda dan anak-anak Tajung yang lulus sarjana (S.1). Barometer lainnya, sampai sekarang tidak ada satupun lembaga pendidikan formal yang berdiri di Dukuhan Tajung. Hanya terdapat satu musholah yang baru berdiri dua tahun silam yang digunakan aktifitas keagamaan dengan diasuh oleh ustadz dari desa tetangganya, Beji, Kecamatan Jenu. Jika ingin sekolah, anak-anak warga Desa Tajung keluar dari dukuhannya. Paling dekat ada di Desa Kaliuntu (menjadi pusat pemerintahannya) yang berjarak sekitar 2 kilometer dari Dusun Tajung. Meski jaraknya tidak terlalu jauh dari Dukuhan Tajung, tapi kesadaran masyarakatnya tentang pentingnya pendidikan masih belum muncul. Sebagaimana wawancara dengan kepala desa Kaliuntu bahwa: "Hanya sedikit sekali warga Tajung yang mau menyekolahkan anak-anaknya. Kesadaran menyekolahkan anak itu masih sangat minim. Paling banter, anak-anak warga Dukuhan Tajung sekolah Madrasah Aliyah, itu bisa dihitung dengan jari."

\section{Genealogi Manusia dan Alam: Dari Eco- Biosentris ke Antroposentris}

Hubungan manusia dengan lingkungannya mengalami perubahan secara terus menerus. Perubahan hubungan antara manusia dan alam ini, terutama terkait dengan etika manusia terhadap lingkungannya. Dari beberapa lieteratur, etika manusia terhadap alam, setidaknya bisa dijelaskan sebagai berikut: a. Eco-Biosentris

Didominasi

Masyarakat Tradisional

Pada masyarakat tradisional, etika manusia terhadap alam masih memiliki kedudukan sederajat. Kesamaan derajat antara manusia dan alam ini oleh Sonny Keraf disebut sebagai Biosentrisme. Posisi seperti ini, manusia sangat menghormati terhadap alam dan tidak melakukan eksploitasi untuk menghabisi alam demi kepentingan manusia. Alam dipelihara dengan baik. Kedudukan yang setara ini menempatkan posisi manusia dengan alam sederajat dan sama-sama sebagai cipataan Tuhan. Manusia menganggap dirinya sebagai bagian dari alam, karenanya alam harus dilindungi. (Keraf, 2010).

b. Masyarakat Animisme: Alam Sebagai Makrocosmos

Masyarakat tradisional yang masih tergolong animisme memiliki anggapan, manusia lebih kecil dibandingkan lingkungan/alam. Manusia disebutnya sebagai mikrokosmos dan alam sebagai makrokosmos. Manusia animisme berusaha mengikuti irama atau ritme lingkungan/alam, bahkan tidak berani mengganggu lingkungan sekitarnya, kecuali dilakukan spiritual tertentu. Lingkungan dan alam dianggap memiliki kekuatan, keramat. Misalnya bagi masyarakat tradisional dalam menyikapi sebuah pohon besar, mereka tidak akan berani memotong, karena pohon dianggap memiliki kekuatan-bahkan dalam kepercayaan animisme pohon dipuja-puja atau menjadi tempat pemujaan. Jika ingin merobohkan pohon tertentu, masyarakat tradisional bahkan harus melakukan kegiatan spiritual, misalnya membawa sedekah atau 
bancaan bersama tetangganya. (Wardiman et al., 2020).

Contoh lain, bagaimana masyarakat memperlakukan laut yang sehari-hari dipetik hasilnya. Bagi nelayan tradisional, laut menjadi teman yang patut dihormati dan disayangi. Tidak heran, di beberapa tempat di Jawa yang dihuni nelayan tradisional, masih terdapat acara untuk menghormati laut, yang biasa disebutnya sebagai sedakah laut. Dalam prakteknya, beberapa jenis makanan yang biasa dimakan oleh manusia dilarung ke tengah laut (larung sesaji). Kegiatan tahunan yang biasa dilakukan oleh nelayan tradisional membuktikan bahwa mereka meyakini laut menjadi macrokosmos, ada kekuatan lebih dibanding kekuatan manusia, sehingga harus dihormati. Bukan hanya itu, dari sisi tindakan (cara memburu ikan) di laut, antara nelayan tradisional dengan nelayan modern juga mengalami perbedaan. Nelayan tradisional lebih santun (tidak merusak alam) dalam mencari ikan di laut, turumbu karang tidak rusak karena perilaku santun nelayan tradisional kepada laut. Perilaku beda ditunjukkan oleh nelayan modern, yang datang ke laut membawa jaring ikan jenis pukat harimau (jenis jaring ikan yang bisa merusak terumbu karang yang menjadi ekosistem alam laut untuk keberlangsungan hidup ikan). Bukan hanya itu, nelayan modern tidak jarang juga membawa granat untuk membuat klenger ikan saat proses penangkapan ikan laut. (Oprasmani et al., 2020).

Di daratan, orang-orang tradisional juga menghormati bumi yang diinjaknya, misalnya terdapat upacara sedakah bumi. Secara empirik, kondisi seperti ini masih kerap terjadi di belahan bumi Jawa. Sedekah bumi merupakan kegiatan masyarakat tradisional, yang sampai sekarang masih kerap terjadi di beberapa belahan pulau Jawa, termasuk di banyak tempat di Jawa Timur.

Amukan alam yang berjalan dari masa ke masa ini, diyakini orang-orang tradisional bahwa alam memiliki kekuatan. Amukan alam ini terjadi hampir di seluruh belahan dunia, termasuk di negara maju sekalipun (negara yang mengklaim dirinya maju di bidang Iptek-sebut saja Amerika dan Jepang), juga sering terjadi bencana alam yang memporak-porandakan tatanan peradaban manusia.

Misalnya di Amerika sering terjadi musibah alam Angin Tornado yang menghampaskan setiap benda yang dilintasi. Di Indonesia, juga terjadi angin putting beliung dan bahkan sekali waktu terjadi gampa yang cukup dahsyat, gempa tsunami, seperti terjadi gempa tsunami di Aceh beberapa tahun lalu yang melululantakkan hampir semua peradaban manusia di Aceh.

Meski alam memiliki kekuatan yang bisa menghempaskan dalam hitungan menit terhadap peradaban manusia yang dibangun berabad-abad lamanya, tetapi sebagian manusia masih belum menyadari bahwa ia kalah oleh kekuatan alam yang digerakkan Tuhannya. Tidak sedikit manusia yang memiliki keahlian Iptek mengakui dirinya seolah-olah telah menguasai alam dan mampu mengendalikannya. Tentu hipotesa bahwa 'manusia dengan penguasaan iptek tinggi mampu mengendalikan alam', telah terbantahkan dengan peristiwa-peristiwa alam yang terjadi hampir seluruh belahan 
Hikmah, Vol. 18, No. 2, Juli-Desember 2021， p-ISSN: 1829-8419 e-ISSN: 2720-9040

dunia. Meminjam istilah Borrong, dengan Iptek manusia seolah-olah menjadi dewa dan tuhan atas alam.

Keberadaan Ilmu Pengetahuan dan Teknologi (Iptek), membuat manusia seolaholah (sekali lagi seolah-olah) menjadi penguasa alam dan sekaligus pengendali alam. Tetapi tidak semua alam bisa dikendalikan oleh manusia dengan keahlian di bidang Iptek-nya. (Idris et al., 2021).

Robert P. Borrong, menyebutnya, kondisi seperti di Jawa itu juga terjadi di beberapa belahan dunia, sebut saja misalnya di masa Mesir Kuno, Yunani Kuno, India, Jepang. Bahkan di Bali, masyarakat beragama Hindu yang animism itu sangat menjunjung tinggi lingkungan, termasuk bagaimana masyarakat Bali memperlakukan terhadap pepohonan. Tidak jarang, batang pohon dibalut dengan kain untuk menjaga melestarikan alam. Jika mau menebang, dilakukan sederat ritual dalam proses menjelang penebangan pohon. (Borrong, 1999).

Pola kesetaraan manusia dengan alam ini sampai sekarang masih ada, tetapi semakin ke sini semakin mengalami penyusutan dari sisi kuantitasnya. Penyusutan ini dipicu oleh kemajuan teknologi yang semakin lama semakin memengaruhi manusia untuk berpikir praktis pikiran dilandasi oleh nilai untung dan rugi. Sehingga yang terjadi adalah bagaimana lingkungan bisa dimanfaatkan atau dengan bahasa lebih keras diekplorasi untuk didapatkan hasilnya. (Khair, 2013).

Akibat dari terciptanya harmonisasi antara manusia dan alam, di antaranya, kehidupan lebih tenang dan kesehatan lebih terjamin karena oksigen terpenuhi dengan baik, tidak rentan terkena penyakit.

c. Eco-Antroposentris: Manusia modern mengeksploitasi lingkungan

Era sekarang, teknologi mendominasi manusia yang menyebabkan terjadinya pergeseran antara manusia dan alam, yang semula duduk setara atau bahkan tidak jarang terjadi manusia sebagai microkosmos dan alam menjadi macrokosmos, berubah menjadi manusia menguasai (eksploitasi) alam. Terjadi 'pemaksaan' di sana sini oleh manusia terhadap alam. Sikap yang semula mengharmoni, kemudian berubah sikap menjadi pengeksploitasi, penguasa tanpa batas, dan menjadi penindas alam.

Sikap mengekploitasi alam oleh manusia ini, oleh Sonny Keraf, disebut sebagai tindakan antorposentrisme, yaitu pemahaman yang beranggapan bahwa semua makhluk yang diciptakan di dunia ini hanya untuk kepentingan manusia.

Dengan pemahaman antroposentrisme itu, menyebabkan seakan-akan tindakan manusia yang merugikan alam, menjadi sesuatu yang dibenarkan. Sikap seperti itu dilakukan oleh orang-orang sekarang, yang menganggap dirinya maju. Semakin tinggi kebudayaan manusia, semakin beragam kebutuhannya. Namun kebutuhan manusia sering tidak bisa dipisahkan dari keinginan yang tak terbatas. Akibatnya, ilmu pengetahuan dan teknologi digunakan untuk mengeksploitasi lingkungan. Keinginan manusia yang tak terbatas itu menyebabkan kerakusan manusia (materialism) yang mendorong pengekploitasian tak terbatas terhadap sumber-sumber alam, karena manusia mengambil dari alam lebih dari 
sekedar yang dibutuhkan. Dalam posisi ini, manusia dalam behubungan dengan alam, manusia memiliki kecenderungan menjadi penguasa alam bukan partner, yang bisa berdampingan, mencipatkan keharmonisan, dan keselarasan.

Akibatnya ketika perilaku ekploitasi alam berlangsung oleh manusia, maka yang terjadi adalah bencana alam di mana-mana melanda manusia. Banjir, tanah longsor hampir setiap tahun mewarnai kondisi alam, bukan hanya di Indonesia, tetapi hampir di seluruh belahan dunia, termasuk negara maju sekalipun, seperti Jepang. Belum lagi, penipisan ozon yang terus mengalami kemajuan (semakin menipis), kemudian polusi udara yang bisa menimbulkan banyak penyakit, diantarnya, penyakir pernapasan, penyakit kulit dan beberapa penyakit lain yang ditimbilkan oleh lingkungan tidak bersih.

\section{Dalil Advokasi Lingkungan Hidup dan Sikap Pemeluknya}

Agama atau religi adalah keyakinan yang bersumber dari Tuhan dengan berpatokan pada wahyu. Keyakinan dalam agama tersebut menjadi legitimasi dari setiap perilaku. Agama bukan hanya mengajarkan ritual, tetapi agama juga mengajarkan bagaimana dalam mencari ekonomi, dalam membangun hubungan antarmanusia (sosial), dalam membangun lingkungan sosial dan mengatur manusia dalam menjaga alam atau dengan bahasa lain disebut realitas sosial. (Marifatullah et al., 2021). Talcott Parsons, menjelaskan, agama merupakan suatu komitmen terhadap perilaku, agama tidak hanya kepercayaan, tetapi perilaku atau amaliah. Apa yang disampaikan Talcott memberikan penjelasan, bahwa orang yang mengaku beragama tidak cukup dengan kegiatan ritual, seperti shalat, puasa dan ritual lainnya, tetapi harus dibarengi dengan perilaku. Durkheim memberikan definisinya, agama adalah suatu system kepercayaan dan praktik yang telah dipersatukan dengan halhal yang kudus kepercayaan dan praktikpraktik yang bersatu menjadi suatu komunitas moral yang tunggal.

Bagaimana ayat-ayat Al-Qur'an dalam memberikan bimbingan atau advokasi kepada pemeluknya (muslimin). Berikut beberapa ayat advokasi lingkungan dan prilaku pemeluknya:

a. Dalil advokasi lingkungan hidup

Perhatian Al-Qur'an terhadap lingkungan sangat tinggi. Demikian yang disampaikan Dr. Maurice Buceille, seorang sarjana Barat yang melakukan kajian secara serius terhadap Al-Qur'an. Maurice mengatakan, Al-Qur'an dalam memberikan perhatiannya terhadap lingkungan sangat tinggi dan memberikan porsi yang jauh lebih dari cukup. (Bucaille, 1979)

Berikut beberapa ayat dalam Al-Qur'an yang memperhatikan lingkungan:

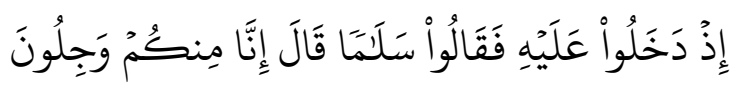
Artinya: Ketika mereka masuk ke tempatnya, lalu mereka mengucapkan: "Salaam". Berkata Ibrahim: "Sesungguhnya kami merasa takut kepadamu". (Q.S. al-Hijr [15]: 52).

Dalam ayat tersebut, dijelaskan bahwa Allah betul telah mengatur alam ini (tumbuhtumbuhan) yang tidak lepas dari kehendakNYA. Allah meniupkan angina yang menyebabkan terjadi perkawinan pada tumbuhan kemudian tumbuhan itu menjadi 
Hikmah, Vol. 18, No. 2, Juli-Desember 2021， p-ISSN: 1829-8419 e-ISSN: 2720-9040

berkembang biak.

Selain ayat tersebut, ayat lain yang juga membicarakan tentang lingkungan yakni:

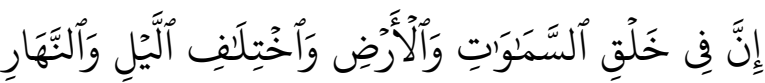

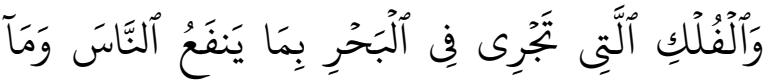

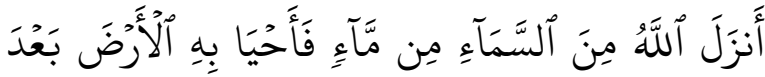

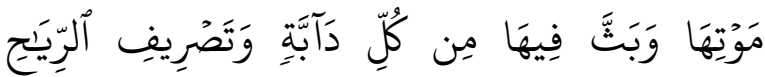

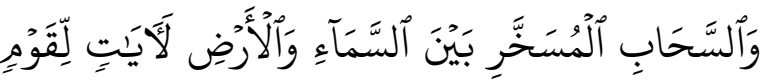

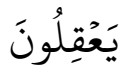

Artinya: Sesungguhnya dalam penciptaan langit dan bumi, silih bergantinya malam dan siang, bahtera yang berlayar di laut membawa apa yang berguna bagi manusia, dan apa yang Allah turunkan dari langit berupa air, lalu dengan air itu Dia hidupkan bumi sesudah mati (kering)-nya dan Dia sebarkan di bumi itu segala jenis hewan, dan pengisaran angin dan awan yang dikendalikan antara langit dan bumi; sungguh (terdapat) tanda-tanda (keesaan dan kebesaran Allah) bagi kaum yang memikirkan. (Q.S. al-Baqarah [2]: 164)

Pada ayat lain di surah Al-Baqarah juga dijelaskan serupa:

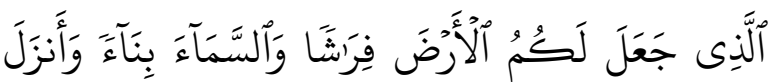

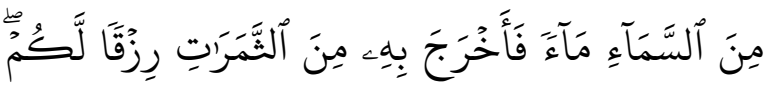

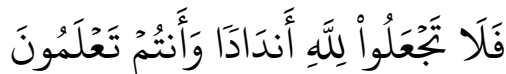

Artinya: Dialah yang menjadikan bumi sebagai hamparan bagimu dan langit sebagai atap, dan Dia menurunkan air (hujan) dari langit, lalu Dia menghasilkan dengan hujan itu segala buah-buahan sebagai rezeki untukmu; karena itu janganlah kamu mengadakan sekutu-sekutu bagi Allah, padahal kamu mengetahui. (Q.S. al-Baqarah [2]: 22)
Dukungan Al-Qur'an terhadap penjagaan lingkungan memang sangat kuat, termasuk Allah menyinggungnya, bahwa seluruh makhluk yang diciptakannya ini tidak diciptakan dengan sia-sia. Nana maharani memberikan penjelasan, bahwa alam semesta diciptakan oleh Allah bukan tanpa tujuan, aka tetapi dengan tujuan tertentu, dan itulah yang menjadi mukjizat Al-Qur'an bahwa kadangkala tujuan itu relevn dengan masa modern saat ini, yang mungkin dulu tidak ditemukan relevansinya. (Mahrani, 2021). sebagaimana ayat Al-Qur'an yang dikutipnya:

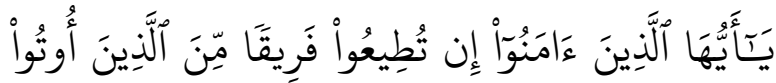

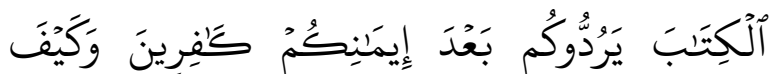

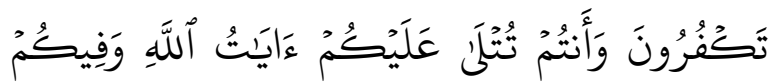

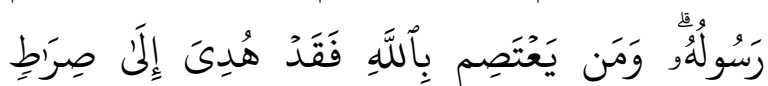
مُسُسنَقِيمِِ Artinya: Hai orang-orang yang beriman, jika kamu mengikuti sebahagian dari orang-orang yang diberi Al Kitab, niscaya mereka akan mengembalikan kamu menjadi orang kafir sesudah kamu beriman. Bagaimanakah kamu (sampai) menjadi kafir, padahal ayat-ayat Allah dibacakan kepada kamu, dan RasulNya pun berada di tengah-tengah kamu? Barangsiapa yang berpegang teguh kepada (agama) Allah, maka sesungguhnya ia telah diberi petunjuk kepada jalan yang lurus. (Q.S. Ali Imran [3]: 100-101)

Hutan yang dibabat habis, akan mempengaruhi kesuburan tanah dan juga mengakibatkan banjir bandang pada musim hujan. Saat musim kemarau bisa menimbulkan kekeringan berkepanjangan, yang bisa mengganggu kehidupan manusia, binatang dan tumbuh-tumbuhan akibat tidak bisa menyerap air dengan baik. Semua 
makhluk di sekitar aliran sungai membutuhkan air.

Ayat laintentang larangan Allah kepada manusia berbuat kerusakan di muka bumi.

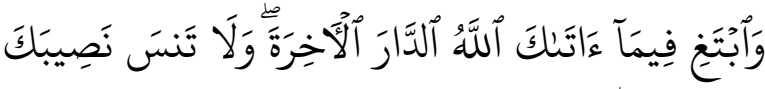

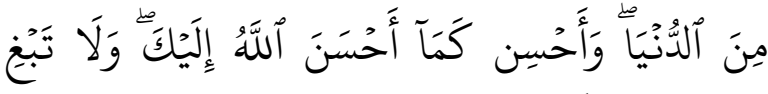

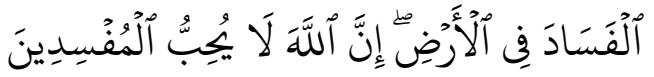

Artinya: Dan carilah pada apa yang telah dianugerahkan Allah kepadamu (kebahagiaan) negeri akhirat, dan janganlah kamu melupakan bahagianmu dari (kenikmatan) duniawi dan berbuat baiklah (kepada orang lain) sebagaimana Allah telah berbuat baik, kepadamu, dan janganlah kamu berbuat kerusakan di (muka) bumi. Sesungguhnya Allah tidak menyukai orangorang yang berbuat kerusakan. (Q.S. alQasash [28]: 77).

Ayat tersebut menjelaskan, bahwa Allah menciptakan sesuatu tidak sia-sia dan manusia dilarang untuk berbuat kerusakan di muka bumi. Hal mengandung makna untuk memberikan keseimbangan di muka bumi, manusia tidak boleh bertindak yang merugikan terhadap alam dan makhluk lain.

b. Sikap muslim terhadap ayat lingkungan hidup

Hasil riset Yale Center for Environmental Law \& Policy (YCELP) dan Center for International Earth Science Information Network (CIESIN) di Kolumbia menyebutkan 10 negara terbersih di dunia tahun 2016 adalah negera-negara yang penduduknya bukan mayoritas muslim apalagi negara muslim. YCELP dan CIESIN dalam risetnya melakukan penilain dengan mengembangkan Indeks tentang Perlindungan Lingkungan Hidup yang dinamai dengan Environment Protection Index (EPI). Indeks ini untuk melakukan penilaian terhadap 178 negara di dunia dan menyusun peringkat sesuai dengan Indeks tersebut. Indeks Perlindungan Lingkungan atau Environment Protection Index (EPI) ini meliputi 20 Indikator yang terdiri dari Kualitas Udara, Air, Perlindungan Habitat serta dampak lingkungan terhadap kesehatan populasinya.

Tabel 1. Sepuluh Negara Terbersih di Dunia dan Jumlah Penduduk Muslimnya

\begin{tabular}{|c|c|c|c|}
\hline No & Negara & Nilai & Jumlah Penduduk \\
\hline 1 & Swiss & 87,67 & $\begin{array}{l}\text { Totol Penduduk: } \\
7.500 .000 . \\
\text { Penduduk Muslim: } 400 \\
\text { ribu atau 4,26 persen. } \\
\text { (hasil sensus 2009) }\end{array}$ \\
\hline 2 & $\begin{array}{l}\text { Luksemb } \\
\text { urg }\end{array}$ & 83,29 & $\begin{array}{l}\text { Total Penduduk:525.000 } \\
\text { Penduduk Muslim : } \\
10.000\end{array}$ \\
\hline 3 & Australia & 82,40 & $\begin{array}{l}\text { Total } \\
\text { Penduduk:23.130.000 } \\
\text { (sensus 2013). } \\
\text { Penduduk Muslim: } \\
340.000 \text { (sensus 2006) }\end{array}$ \\
\hline 4 & Singapura & 81,78 & $\begin{array}{l}\text { Total Penduduk: } \\
5.399 .000 . \\
\text { Penduduk } \\
\text { Muslim:727.870. (sensus } \\
\text { 2013) }\end{array}$ \\
\hline 5 & $\begin{array}{l}\text { Republik } \\
\text { Ceko }\end{array}$ & 81,47 & $\begin{array}{ll}\text { Total } & \text { Penduduk: } \\
10.627 .448 & \end{array}$ \\
\hline 6 & Jerman & 80,47 & $\begin{array}{l}\text { Total Penduduk: } \\
80.620 .000 \\
\text { Penduduk Muslim : } \\
\text { 293.000 (sensus 2013) }\end{array}$ \\
\hline 7 & Spanyol & 79,79 & $\begin{array}{lr}\text { Total } & \text { Penduduk: } \\
80.996 .685 & \\
\text { Penduduk } & \text { Muslim } \\
: 700.000 & \end{array}$ \\
\hline 8 & Austria & 78,32 & $\begin{array}{l}\text { Penduduk: } \\
\text { Muslim : }\end{array}$ \\
\hline 9 & Swedia & 79,09 & $\begin{array}{l}\text { Total } \\
9.723 .809 \\
\text { Penduduk } \\
25.000\end{array}$ \\
\hline 10 & Norwegia & 78,04 & $\begin{array}{ll}\text { Total } & \text { Penduduk: } \\
5.147 .792 & \\
\text { Penduduk } & \text { Muslim : } \\
80.000 .000 & \end{array}$ \\
\hline
\end{tabular}


Hikmah, Vol. 18, No. 2, Juli-Desember 2021， p-ISSN: 1829-8419 e-ISSN: 2720-9040

Data tersebut sengaja disampaikan untuk menjelaskan, bahwa tuntunan agama Islam yang berada dalam kitab sucinya, al Qur'an yang sangat baik untuk menata kehidupan masyarakat, termasuk menata lingkungan itu masih bersifat tekstual, belum berhasil diterjemahkan secara kontektual dalam kehidupan masyarakat, termasuk bagaimana membangun lingkungan sebagaimana dianjurkan oleh Islam.

Dari sepuluh negara terbersih di dunia itu, penduduk muslimnya rata-rata tidak lebih dari 25 persen. Sedangkan beberapa negara yang mayoritas penduduknya muslim, belum mampu menunjukkan nilai-nilai Islam, termasuk bagaimana menciptakan lingkungan sehat dan bersih. Arab Saudi, Malaysia, Indonesia, merupakan negara yang dihuni oleh mayoritas muslim, tetapi belum mampu menunjukkan kepada dunia terkait pelaksanaan nilai-nilai lingkungan bersih.

Dari data tersebut, seakan-akan terjadi tolak belakang antara teks Al-Quran yang sangat massif menyerukan melindungi alam, berbuat bersih dan bersikap baik terhadap alam, tetapi di pihak lain orang yang mempercayai Al-Quran (muslimin) belum menunjukkan jati dirinya sebagai muslim sejati, dengan mengambil Al-Qur'an sebagai tuntunan hidupnya. Data tentang 10 negara terbersih di dunia menjadi salah satu bukti, bahwa negara-negara muslim belum mampu menjadi negara bersih di dunia.

Inilah yang disinggung dalam AlQur'an, bahwa Allah menganjurkan orang beriman untuk masuk Islam secara kaffah.

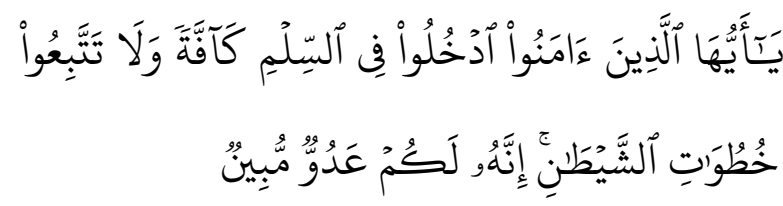

Artinya: Hai orang-orang yang beriman, masuklah kamu ke dalam Islam keseluruhan, dan janganlah kamu turut langkah-langkah syaitan. Sesungguhnya syaitan itu musuh yang nyata bagimu. (Q.S. Al Baqarah [2]: 208).

Kepribadian muslim yang kaffah (utuh) kepribadian yang mampu menerjemahkan hubungan manusia dengan Tuhannya, hubungan manusia dengan manusia lainnya, dan hubungan manusia dengan alam. Karenanya, agar Islam tidak sekedar menjadi pengetahuan, dibutuhkan proses internalisasi nilai-nilai Islam dalam kehidupan pemeluknya.

Siapa muslim kaffah itu, yaitu muslim yang memiliki kepribadian yang mampu menerjemahkan hubungan manusia dengan Tuhannya, hubungan manusia dengan manusia lainnya, dan hubungan manusia dengan alam. Karenanya, agar Islam tidak sekedar menjadi pengetahuan, dibutuhkan proses internalisasi nilai-nilai Islam dalam kehidupan pemeluknya.

Mujamil Qomar, menyebutnya Islam di Indonesia ini seolah-olah hanya seperti legenda. Umat Islam begitu bersemangat menyebut dirinya Islam, tetapi enggan mengamalkan dalam semua aspek kehidupan. Ringkas kata, Islam hanya dipahami sebagai pengetahuan dan tidak diaktualisasikan sebagai amalan. (Qomar, 2013).

\section{Eco-Pedagogi Berbasis Religi Bagi Masyarakat Pesisir Tuban}

Tingkat religiositas masyarakat pesisir Desa Kaliuntu, Kecamatan Jenu, jika diukur dengan jumlah tempat ibadah (sebagaimana dijelaskan di atas), maka bisa dikategorikan 
sebagai masyarakat yang tingkat keberagamaannya cukup bagus. Apakah setiap yang tingkat keberagamaannya tinggi, juga mempengaruhi terhadap kepedulian terhadap lingkungannya juga tinggi?. Dari hasil penelitian menyebutkan, masyarakat yang tingkat keagamaannya tinggi, semakin tinggi tingkat kepeduliannya terhadap lingkungan.

Menurur reseacher, yang membedakan hanyalah tingkat pemahaman terhadap ayatayat Al-Qur'an yang menjelaskan tentang pentingnya umat muslim memperhatikan lingkungan. Sebagian masih memahami teksteks ayat al-Qur'an sebagai ayat yang hanya dibaca, tidak dipraktekkan untuk kehidupan. Tetapi pemahaman teks bukanlah satusatunya penyebab tidak pedulinya masyarakat terhadap lingkungannya, persoalan lain, misalnya persoalan kuat dan lemahnya ekonomi. Semakin kuat ekonomi seseorang, maka kepedulian terhadap lingkungan semakin tinggi.

Soal ekonomi inilah oleh reseacher, yang disebut sebagai tipologi masyarakat mapan dan masyarakat tidak mapan. Masyarakat mapan disebut sebagai masyarakat yang tingkat kepeduliannya lebih tinggi dibanding masyarakat yang tidak mapan. Mereka yang telah mapan secara ekonomi, rupanya tidak ingin rumah dan lingkungan sekitarnya kumuh. Terlihat, beberapa rumah yang sudah berkeramik, tidak terlihat kotoran berserakan, termasuk kotoran sapi di dekat lokasi atau pekarangan rumah tersebut. Tetapi itupun juga tidak terdapat pada setiap rumah, masih ada juga halaman dari rumah yang berkeramik dihiasi oleh kotoran sapi.
Apakah ada relevansinya, ketinggian pemahaman keagamaan dengan sikap bersih terhadap lingkungannya. Menurut analisa reseacher, yang mengambil konklusi dari sederet fakta empiris di Desa Kalintu, bahwa agama tidak sepenuhnya bisa mengubah perilaku masyarakat, tergantung bagaimana pelaku agama itu dalam menjalankan nilainilai agamanya. Rentetan skemanya adalah ketika seseorang sudah memahami teks wahyu, kemudian nilai-nilai teks wahyu diinternalisasi, terciptalah sebuah tindakan yang berbasis agama/teks wahyu. Mafhum mukholafahnya (akronimnya), bahwa pemahaman teks wahyu saja tidaklah cukup untuk mengubah perilaku masyarakat. Hal itu sama dengan kalimat berikut, bahwa 'Bisa membaca Al-Qur'an saja tidak cukup untuk mengantarkan seseorang itu menjadi shaleh (baik terhadap lingkungan).' Tapi membaca Al-Qur'an yang ditambah dengan internalisasi nilai-nilai ayat, baru memunculkan perilaku. Pemahaman bahwa agama mampu mengantarkan manusia menjadi orang yang mencintai lingkungannya, dijelaskan seperti skema rotasi di bawah ini:

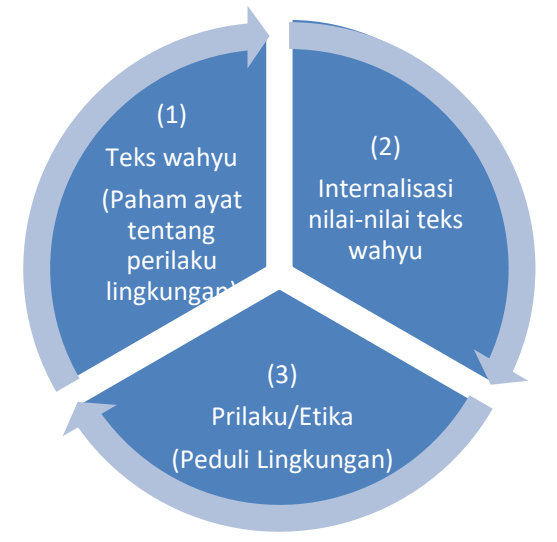

Bagan 1. Kaitan agama dan lingkungan

Jika salah satunya pincang, artinya dari ketiganya tidak menjadi satu kesatuan yang 
Hikmah, Vol. 18, No. 2, Juli-Desember 2021， p-ISSN: 1829-8419 e-ISSN: 2720-9040

utuh, maka bisa dipastikan bahwa agama tidak akan memiliki pengaruh terhadap sebuah tindakan untuk hidup bersih. Misalnya, masyarakat paham atau bahkan mahir dalam melafalkan dan memaknai sebuah teks Al-Qur'an, tetapi tidak sampai merasuk pada internalisasi nilai-nilainya, maka tidak akan terjadi perilaku sebagaimana ayat yang dipahaminya. Begitu juga, ketika masyarakat tidak paham teks, maka proses internalisasi nilai akan terkendala, karena tidak materi yang bisa diinternalisasi. Ketiganya harus muncul bersama-sama, jika menginginkan agama memiliki pengaruhnya terhadap pelestarian lingkungan.

Beberapa hal telah dilakukan dalam eco-pedagogi berbasis religi bagi masyarakat pesisir Tuban, diantaranya:

a. Membangkitkan kesadaran masyarakat mencintai lingkungannya

Membangkitkan kesedaran masyarakat di tengah himpitan ekonomi tentu tidak sama dengan membangun kesadaran di tengahtengah ekonomi yang sudah mapan, apalagi kesadaran yang dimaksud adalah kesadaran berimplikasi pada pengeluaran uang dari saku masyarakat. Tentu kondisi ini sangat sulit untuk membangun perubahan yang diawali dengan membangun kesadaran masyarakat.

Dalam penelitian ini, proses mengubah pola pikir dan prilaku masyarakat dari hidup tidak bersih menjadi hidup bersih dengan pendakatan Community Based Risearch (CBR) adalah sebuah pilihan agar masyarakat tidak merasa digurui, tetapi merasakan bahwa kesadaran itu munculnya dari dirinya sendiri. Reseacher sengaja melibatkan masyarakat dalam mengubah lingkungan - terutama dengan pendekatan perubahan perilaku--, untuk tidak mengeluarkan biaya terlalu mahal. Lingkungan yang dibangun atas keinginan masyarakat itu sendiri, akan dengan sangat mudah dan tanpa banyak mengeluarkan biaya, lingkungan itu lambat tapi pasti akan terus bermetamorfosa, sesuai semangat masyarakatnya menuju kepada lingkungan yang lebih sehat.

Proses melibatkan masyarakat dalam membangun kesadaran inilah yang menjadi proses paling rumit dalam penelitian ini. Tentu kerumitan itu tidak menghentikan niat reseacher untuk melanjutkan penelitiannya, tetapi dengan berbagai cara, proses penyadaran masyarakat harus tetap berjalan. Tentu proses yang rumit dengan waktu dan biaya yang sangat terbatas, membutuhkan berbagai strategi untuk bisa diterima oleh masyarakat desa Kaliuntu. Membangun kesadaran tanpa dibarengi dukungan factor lain, misalnya dukungan dari perangkat desa dan dukungan dari elemen-elemen lain, akan memperlambat proses terjadinya perubahan.

\section{Membangun keterlibatan stakeholders}

Menurut reseacher, perubahan lingkungan masyarakat Kaliuntu tidak akan bisa dirubah dalam hitungan tiga tahun ke depan, jika tidak didukung oleh stakeholders, terutama sebagai sumber pembiayaan. Kesadaran yang tumbuh, kemudian tidak dibarengi dengan kemampuan sacara ekonomi membangun sarana prasarana, maka kesadaran itu hanya sebatas pada wilayah ide. Sebaliknya kesadaran yang sudah mulai tumbuh pada masyarakat, meski kesadarannya masih belum penuh, tetapi 
sudah ada bibit kesadaran kalau mendapatkan dukungan dana dari pihak ketiga, meraka akan bisa cepat melakukan perubahan, apalagi semua eleman masyarakat, termasuk pemerintah mendukungnya, bisa dipastikan perubahan tidak lama akan segera terjadi. Pendapat tentang perubahan lingkungan itu bisa diskemakan sebagaimana berikut:

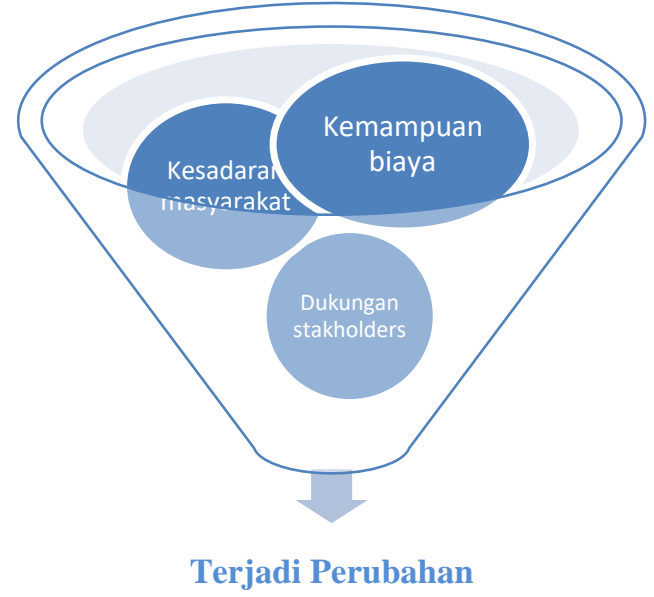

Bagan 2. Alur Perubahan Lingkungan

Sebaliknya, tumbuhnya kesadaran masyarakat, tanpa dibarengi dengan kemampuan biaya dan dukungan stakeholders, maka diyakini tidak akan terjadi perubahan. Inilah yang sekarang terjadi di Desa Kaliuntu, terutama di Dusun Tajung yang menjadi pusat perhatian pada penelitian kali ini. Di dusun Tajung, selain kesadarannya masih tipis (+) kemampuan biaya minim (+) kurang mendapatkan dukungan stakeholders (=) tidak mengalami perubahan.

Perubahan lingkungan tidak akan mengalami perubahan, ketika elemen-elemen itu tidak menyatu menjadi satu kesatuan yang utuh untuk mendukung sebuah perubahan. Apabila dari tiga elemen (sebagaimana skema di atas), belum bisa memadu menjadi satu kesatuan, maka yang terjadi adalah perubahan tidak akan terjadi. Tetapi sebaliknya, jika tiga elemen tersebut menyatu menjadi satu kesatuan, dalam wkatu dekat perubahan - dari lingkungan kotro menjadi lingkungan bersih-bakal terjadi, meski waktuya tergantung seberapa kuat ikatan ketika elemen dalam melaksanakan komitmennya, menciptakan lingkungan bersih.

\section{SIMPULAN}

Kondisi ekonomi yang lemah, membuat masyarakat Dusun Tajung, Desa Kaliuntu, harus rela hidup dengan suasana lingkungan yang sangat kumuh. Tetapi kondisi seperti ini dianggap sesuatu yang 'nyaman' tidak ada keluhan--, karena sudah biasa dirasakan setiap hari. Sesuatu yang dirasakan setiap hari secara terus menerus dengan waktu yang lama, akan dianggap menjadi sesuatu yang biasa, meski oleh kebanyakan orang, sesuatu itu tidak biasa. Misalnya, yang terjadi di Dusun Tajung, Desa Kaliuntu, Kecamatan Jenu, meski di sekitar rumahnya dikelilingi sapi dan kotorannya, tetapi mereka dengan rasa nyaman makan di dekat kotoran sapi. Kekebalan terhadap lingkungan hunian yang kumuh, bukan berarti tidak perlu untuk dirubah, tetapi mengubah menjadi suatu keniscayaan. Sebagai masyarakat yang agamis, pendekatan agama menjadi salah satu jalan untuk mengubah masyarakat yang sudah kebal terhadap lingkungan kumuh. Dengan teks-teks wahyu tentang lingkungan menjadi penting untuk dipahamkan kepada masyarakat yang telah menderita kebal terhadap lingkungan negatif (kumuh). Tetapi memahami teks-teks wahyu saja tidak 
Hikmah, Vol. 18, No. 2, Juli-Desember 2021， p-ISSN: 1829-8419 e-ISSN: 2720-9040

cukup tanpa diikuti oleh internalisasi nilai, yang ujung-ujungnya hanya paham teks, tanpa melakukan tindakan apapun. Penelitian di Desa Kaliuntu, Kecamatan Jenu, Tuban ini menjadi sebuah bukti bahwa tidak semua manusia yang beragama itu bisa menjalankan kehidupan kesehariannya sebagaimana yang dituntunkan agamanya. Mengambilan penelitian pada bagian 'internalisasi nilai agama' dalam kontek pelestarian lingkungan menjadi hal yang penting, karena internalisasi nilai-nilai teks wahyu ini sering menjadi--garis merah pemutus antara idealitas wahyu dengan nilai-nilai tindakan manusia.

\section{DAFTAR PUSTAKA}

Afrina, N. (2020). Menjaga Kelestarian Lingkungan Dalam Perspektif Islam (Edukasi Ajaran Islam Tentang Lingkungan Hidup di Desa Mangunharjo, Kecamatan Jatipurno, Kabupaten Wonogiri) (pp. 18-31). IAIN Ponorogo. http://etheses.iainponorogo.ac.id/id/epri $\mathrm{nt} / 12609$

Borrong, R. P. (1999). Etika Bumi Baru: Akses Etika dalam Pengelolaan Lingkungan Hidup. BPK Gunung Mulia.

Bucaille, M. (1979). Bibel, al-Qur'an dan Sains Modern, Terj: Rasyidi. Bulan Bintang.

Efendy, I. (2016). Konstruksi Pendidikan Kesehatan Lingkungan dalam Perspektif Islam. Miqot: Jurnal IlmuIlmu Keislaman, 40(2), 20-34. http://dx.doi.org/10.30821/miqot.v40i2. 305

Idris, S., Rambe, D., Afriani, D., \& Hastuti, H. (2021). Manajemen Kolaborasi dalam Meningkatkan Mutu Pendidikan Masyarakat (Studi Deskriptif pada
Organisasi Ikatan Keluarga Besar Baringin Sip). Hikmah, 18(1), 1-12. https://doi.org/10.53802/hikmah.v18i1. 100

Ilyasa, F., Zid, M., \& Miarsyah, M. (2020). Pengaruh Eksploitasi Sumber Daya Alam Perairan Terhadap Kemiskinan pada Masyarakat Nelayan. Jurnal Ilmiah Pendidikan Lingkungan Dan Pembangunan, 21(01), 43-58. http://doi.org/10.21009/PLPB.211.05

Imanda, R., Zulheldi, Z., Fithri, W., \& Saputra, E. (2021). Tradisi Tolak Bala Sebelum Tanam Padi pada Masyarakat Desa Simaroken Kabupaten Pasaman (Kajian Living Al-Qur'an). Hikmah, 18(1), 41-53. https://doi.org/10.53802/hikmah.v18i1. 104

Kahn, R. (2008). From Education for Sustainable Development to Ecopedagogy: Sustaining Capitalism or Sustaining Life? Green Theory and Praxis: The Journal of Ecopedagogy, 4(1), 16-23. http://www.criticalanimalstudies.org/wp -content/uploads/2012/11/Vol-4-Issue1-2008.pdf

Keraf, A. S. (2010). Krisis dan bencana lingkungan hidup global. Penerbit Kanisius.

Khair, M. A. (2013). Restorasi Peran Pendidikan Islam Dalam Tatanan Kehidupan Sosial. Tadris: Jurnal Pendidikan Islam, 8(2), 235-248. https://doi.org/10.19105/tjpi.v8i2.393

Mahrani, N. (2021). I'jaz Al-Qur'an dan Relevansinya dengan Perkembangan Ilmu Pengetahuan dan Teknologi. Hikmah, 18(2), 131-149. https://doi.org/10.53802/hikmah.v18i2. 127

Marifatullah, A., Syamsurizal, S., A, A. R., Yanti, N., \& Riana, F. (2021). Efektivitas Program Keluarga Harapan (PKH) dan Dampaknya Terhadap 
Religiositas Masyarakat Penerima Bantuan di Kabupaten Solok. Hikmah, $18(1)$, $54-63$. https://doi.org/10.53802/hikmah.v18i1. 103

Nurulloh, E. S. (2019). Pendidikan Islam dan Pengembangan Kesadaran Lingkungan. Jurnal Penelitian Pendidikan Islam,[SL], 7(2), 237-258. https://doi.org/10.36667/jppi.v7i2.366

Oprasmani, E., Amelia, T., \& Muhartati, E. (2020). Membangun Masyarakat Peduli Lingkungan Pesisir Melalui Edukasi Kepada Masyarakat Kota Tanjungpinang Terkait Pelestarian Daerah Pesisir. To Maega: Jurnal Pengabdian Masyarakat, 3(2), 66-73. http://dx.doi.org/10.35914/tomaega.v3i 2.372

Qomar, M. (2013). Strategi Pendidikan Islam. Penerbit Erlangga.

Smith, S. J. (2021). Swimming in flow motion: an ecopedagogy for health and physical education. Sport, Education and Society, 26(4), 417-428. https://doi.org/10.1080/13573322.2020. 1847065

Sukma, R. N. (2017). Kajian pengelolaan Mangrove di Desa Jenu, Kecamatan Jenu, Kabupaten Tuban, Jawa Timur. Pena Akuatika: Jurnal Ilmiah Perikanan Dan Kelautan, 15(1), 17-23. http://dx.doi.org/10.31941/penaakuatika .v15i1.508

Suwarsih, S. (2018). Pemanfaatan Ekologi dan Ekonomi dari Program Rehabilitasi Mangrove di Kawasan Pesisir Pantai Desa Jenu Kecamatan Jenu Kabupaten Tuban. Techno-Fish, 2(1), 12-18. https://doi.org/10.25139/tf.v2i1.711

Wardiman, W., Maru, R., \& Badwi, N. (2020). Persepsi Masyarakat Tentang Struktur Makrokosmos dan Simbol Konstruksi Rumah Adat Bugis Berdasarkan Geografi Budaya. LaGeografia, 19(1), 128-138. https://doi.org/10.35580/lageografia.v1 9i1.13594

Yasril, Y., \& Nur, A. (2018). Partisipasi Masyarakat dalam Pemberdayaan Lingkungan. Jurnal Dakwah Risalah, 28(1), 1-9. http://dx.doi.org/10.24014/jdr.v28i1.55 38

Yunansah, H., Kuswanto, K., \& Abdillah, F. (2020). Ekopedagogik: Analisis Pola Pendidikan Di Sekolah Alam Bandung. EduHumanioral Jurnal Pendidikan Dasar Kampus Cibiru, 12(2), 115-124. https://doi.org/10.17509/eh.v12i2.20597 